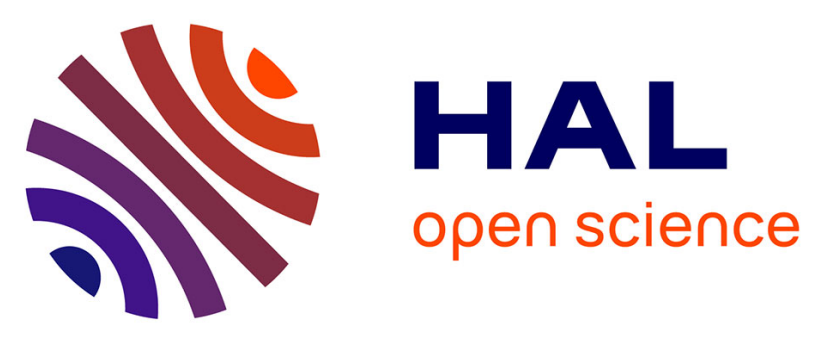

\title{
Menez-Dregan I, layer 4: A transitional layer between the Lower and Middle Palaeolithic in Brittany
}

Anne-Lyse Ravon, Jean-Laurent Monnier, Marine Laforge

\section{To cite this version:}

Anne-Lyse Ravon, Jean-Laurent Monnier, Marine Laforge. Menez-Dregan I, layer 4: A transitional layer between the Lower and Middle Palaeolithic in Brittany. Quaternary International, 2016, 409 (Part B), 92-103, Special Issue: The Hoslteinian period in Europe (MIS 11-9). 10.1016/j.quaint.2015.07.066 . hal-01201996

\section{HAL Id: hal-01201996 \\ https://hal-univ-rennes1.archives-ouvertes.fr/hal-01201996}

Submitted on 17 Feb 2017

HAL is a multi-disciplinary open access archive for the deposit and dissemination of scientific research documents, whether they are published or not. The documents may come from teaching and research institutions in France or abroad, or from public or private research centers.
L'archive ouverte pluridisciplinaire HAL, est destinée au dépôt et à la diffusion de documents scientifiques de niveau recherche, publiés ou non, émanant des établissements d'enseignement et de recherche français ou étrangers, des laboratoires publics ou privés. 
Menez-Dregan I, layer 4: a transitional layer between the Lower and Middle Palaeolithic in Brittany

Anne-Lyse Ravon*, Jean-Laurent Monnier*, Marine Laforge ${ }^{\star *}$

* UMR 6566 CNRS (CReAAH), Université de Rennes 1, Campus de Beaulieu, Laboratoire Archéosciences (bât. 24-25), 74205 CS, 35042 Rennes cedex, FRANCE. E-mail:

anne-lyse.ravon@univ-rennes1.fr

** Éveha, UMR 6566 CNRS (CReAAH), UMR 6554 LETG-Géomer

Abstract :

Menez-Dregan I is a Lower Palaeolithic site situated at Plouhinec, Finistère, in Brittany. It is an ancient marine cave whose roof has gradually collapsed. Layer 4 from the site of MenezDregan I is the last occupation of this deposit, at the boundary between the Lower and Middle Palaeolithic (Ravon and Monnier, 2013). Geological correlations (Laforge, 2012; Monnier et al., 2001) tend to place layer 4 in OIS 9 or 7, although the only TL dating obtained for this level gave an age of $223 \pm 23 \mathrm{ky}$ (Mercier et al., 2004). This study focuses on the lithic industry from the 1991-2004 excavations and was undertaken in order to capture the various types of technical behaviour that could illustrate the transition between the Lower and Middle Palaeolithic. We present the lithic industry of this layer, which simultaneously combines Lower Palaeolithic characteristics, such as large quantities of pebble tools (due to the environment of the site), and the emergence of characteristics that are common to the Middle Palaeolithic, such as standardisation of flake production, or adapting knapping methods to the dimensions of the raw materials (discoid knapping for quartzite, bipolar flaking on an anvil for small flint pebbles). The lithic industry from layer 4 and its three levels $(4 \mathrm{a}, 4 \mathrm{~b}$ and $4 \mathrm{c})$ has been analysed. Layer 4 of Menez-Dregan I has been attributed to the "Colombanian" by J.-L. Monnier on the basis of the composition of its lithic industry (Monnier, 1996): a predominance of cobble tools amongst heavy-duty tools, retouched light-duty tools on flake-supports comprising mostly notches and denticulates, and a knapping method akin to the "SSDA - Clactonian" (wide butts rarely faceted, prominent bulbs, wide open flaking angles, resulting from an alternate flaking of the cores; "système par surface de débitage alternée", Forestier, 1993). The Levallois method is absent, bifaces are absent or extremely rare, and there are few scrapers. The Colombanian proves to be a Lower Palaeolithic industry contemporary with the classic Acheulean, but typologically distinct. However, standardisation of flake production leads us to foresee a change in the lithic industry of layer 4, and allows us to highlight a transitional period from the Lower Palaeolithic to the Middle Palaeolithic in the latest occupation of this deposit. This study is a contribution to the documentation of the diversity and variability of Lower and Middle Palaeolithic lithic industries, demonstrating that the large amount of cobble tools in layer 4 is an unchanged component due to environmental constraints.

Keywords: Menez-Dregan; transition; Lower Palaeolithic; environmental constraints; Colombanian; cobble tools 


\section{Introduction}

Menez-Dregan I is a Lower Palaeolithic site situated at Plouhinec, Finistère, in Brittany (fig. 1). The site is located in the Audierne bay, at the westernmost tip of Brittany. It is an ancient marine cave whose roof has gradually collapsed and thus partly protected the site from erosion (fig. 2). In the current state of research, the stratigraphy within Menez-Dregan displays an alternating sequence of pre-Neanderthal occupation layers and marine deposits, which probably date to between OIS 13 and OIS 7 (Monnier et al., 1994, 1996).

The fauna has not preserved due to the acidic environment, leaving only the lithic industry to show how the human groups who settled at the site lived and, it is worth noting, mastered fire lighting and/or control at a very early date (late OIS 13 or early OIS 12). This study focuses on layer 4, excavated between 1991 and 2004, which appears to be the last occupation of this deposit, at the boundary between the Lower and Middle Palaeolithic (Ravon and Monnier, 2013).

\section{Regional context and chronological attribution}

The Lower Palaeolithic in the Armorican Massif consists of two different groups, which are Acheulean sensu stricto on one side, and "archaic" lithic industries characterised by pebble tools on the other side. The name "Colombanian" has been given to this second group whose type site is Saint-Colomban (Carnac, Morbihan, Brittany) by J.-L. Monnier in the late 80's (Monnier and Le Cloirec, 1985; Monnier, 1996).

The lithic industry of the site of Menez-Dregan has been attributed to the "Colombanian group" by J.-L. Monnier (1996) on the basis of its composition: predominance of cobble tools among the heavy-duty tools, retouched light-duty tools on flake-supports comprising mostly notches and denticulates, and knapping method akin to the "SSDA - Clactonian" (Forestier, 1993). The flakes have prominent bulbs, wide butts rarely faceted and wide open flaking angles, resulting from an alternate flaking of the cores (SSDA - "système par surface de débitage alternée", Forestier, 1993). The Levallois method is lacking, handaxes are absent or extremely rare, and there are very few scrapers. The Colombanian proves to be a facies of the Lower Paleolithic, essentially localised on the south Armorican shoreline, between Crozon and Noirmoutier, contemporary with classic European Acheulean but typologically distinct (Monnier, 1996; Monnier and Molines, 1993; Molines, 1999; Molines et al., 2005). The "Colombanian group" is composed of the sites of St Colomban, la Croix Audran, the island of Groix, Menez-Dregan, Primelin, and Le Bois-de-la-Chaize, plus a large number of isolated finds all along the shore line (fig. 3), and is the subject of a new study that focuses mainly on the Lower Palaeolithic site of Menez-Dregan I (Ravon, in progress).

All the Colombanian sites are located on the current shoreline, sheltered in corridors of marine abrasion or in collapsed marine caves. Settlements are always on ancient marine beaches, this position seems to indicate that the human occupation occurred at the transition between interglacial and glacial periods, in rather mild climatic conditions (Monnier, 1996).

\section{The Lower Paleolithic site of Menez-Dregan : a human settlement in a marine cave}

The site of Menez-Dregan I has been undergoing excavation since 1991. This archaeological operation is part of a multidisciplinary project (Monnier et al., 1996, 2000). The deposit is 
located within the cliff above the current sea level. In Menez-Dregan the sedimentological evidence is strongly reduced because of multiple episodes of marine erosion in the cave (low sedimentary preservation in terms of sedimentation and erosion process). However, the proximity of a section with a longer sedimentary record (Gwendrez cliff) allowed for an attempt at correlation between the different deposits by means of a sedimentological study applied to sandy marker beds (dunes). The resulting new data allowed a more precise chronostratigraphy of this site to be drawn up and contributed to further validation of dating (Monnier et al., 2011; Laforge and Monnier, 2011). The layers are described from the oldest to the most recent as follows (fig. 4):

Layer 9 is the first human occupation of the site, dated from a hearth by ESR at 465000 years \pm 65000 (Monnier et al., 1996, p. 63). The lithic assemblage is composed of more than 2,000 debitage products and heavy-duty tools. Cobble tools have been made on sandstone or microgranite, on large cobbles, big flakes or split cobbles, and have sometimes been retouched in order to create a denticulated edge on the tool (fig. 5). The small tools are retouched with denticulates and notches, mostly on flint and quartz. Some bones were found during the excavation, but in a very poor state of preservation. There are no handaxes or bifacial components in this first layer of palaeolithic occupation.

Layer 8 is a raised beach, with an overlying palaeolithic occupation. It is still undergoing excavation, but the presence of two handaxes was noted.

Layer 7 has been geologically correlated to stage 11 (Laforge and Monnier, 2011). It is a thick humic layer, witnessing a rather dense human occupation (more than 14000 artefacts). At least three different sublevels of human occupation coexist in this layer, suggested by the remains of hearths. The heavy duty tools are mostly composed of choppers and of choppingtools, but some particularly interesting cleavers, made on quartzite cobbles, evoke the Acheulian (fig. 6).

On top of layer 7 is layer 6 . It is a level of human occupation directly on top of a fossil beach. The ESR dating gave an age of 396000 years \pm 45000 on the hearth situated at the basis of the immediate overlying layer 5e (Monnier et al., 1996, p. 63). More than 18000 lithic artefacts were recorded in this layer, composed of debitage products and cobble tools. As far as we know, there are absolutely no handaxes nor material resulting from their manufacture from this layer, however the study of the lithic assemblage is still in progress (Ravon, in progress). Once again, the heavy duty tools mostly comprise of choppers and of few chopping-tools.

The composition of the lithic industry is exactly the same for layer 5 , however some interesting features appear, such as the presence of a pseudo-levallois flake and several bifacial tools (fig. 7). The retouched light duty tools are mostly denticulates and notches which show a great variety of shapes and supports. Some of the choppers, which are numerous in this layer too, were also used as hammerstones. Anthracology studies tend to place the different occupations of layer 5 in OIS 9 (Marcoux et al., in preparation).

The last occupation of the marine cave of Menez-Dregan I occurred in layer 4, and was sealed by layer 3, a sand dune dated by ESR at $141 \pm 16$ ky (Monnier, 1996, p. 63). A head deposit covered this dune, and the top soil formed on top of it.

\section{Layer 4}


The paleoenvironmental data indicates that during the prehistoric occupation of layer 4 the sea level was much lower than at present and the shoreline was probably between 5 and 10 $\mathrm{km}$ further from the site (Lefort et al., 2007). Therefore, the deposit would have stood on top of a high promontory and opened out into a vast landscape, providing strategic shelter for palaeolithic populations who had a clear view of the plain below. The study of charcoal from layer 4 allows us to imagine deep valleys around the site, with abrupt slopes and with the formation of a riparian vegetation along the rivers, with the presence of heath, ash and pines (Monnier et al., 1996, p. 72).

No fireplace was found during the excavation, although some burnt artefacts and numerous charcoals are present in this layer, but a paving structure was noticed (fig. 8). This brings us to the organisation of the dwelling place in layer 4: the paving structure was interpreted as the floor of a probable tent. The addition of this tent to the edge of the rockshelter would have largely increased the available space within the shelter (Monnier et al., 2000).

\subsection{Description of the stratigraphy in layer 4}

Geological correlations tend to place layer 4 in OIS 9 or 7 , although the only TL dating obtained for this level gave an age of $223 \pm 23$ ky (Mercier et al., 2004, p. 258). This would place the occupation of layer 4 in OIS $7 d$ (fig. 9), at an average sea level of - $60 \mathrm{~m}$ (Waelbroeck et al., 2002, fig. 4 p. 299). Therefore, the shoreline could be $10 \mathrm{~km}$ further from the site (fig. 10).

The different transgressions that have occurred on the site had an impact on different levels and have truncated the oldest layers. They are generally affected by erosion pools that formed under the collapsed roof blocks, creating numerous stratigraphic hiatuses and complicating the interpretation of the site, for example the interface layer 4 / layer 5. However, three levels have been identified in layer 4, and are thus described (Monnier et al., 1996):

Level 4a: Laminated, brown and compact silty sand, including marine pebbles and few artefacts. This sediment is coarse and poorly sorted.

Level 4b: Laminated, brown and compact silty sand, including marine pebbles and many artefacts. Presence of angular granitic rocks. This sediment is coarse and poorly sorted.

Level 4c: Silty sand and gravels, with few pebbles and artefacts. Lamellar structure, underlined by blacky and humified clayey beds, molding the shape of the underlying rocks from layer 5 .

\section{2. Lithic industry from layer 4}

14, 909 artefacts were found in this layer (Ravon and Monnier, 2013): 140 in level 4a, 4763 in 4b, 9966 in 4c, plus 40 artefacts in layer 4 which could not be attributed to any of these three sub levels. The different raw materials used are strictly local, and come from marine pebbles in the different raised beaches on or around the site. These raw materials are flint, mainly, then sandstone, quartz, microgranite, quartzite and glossy sandstone, as for all the other layers within the site.

Table 1 shows the composition of the lithic assemblage from layer $4.80 \%$ of the assemblage is composed of flakes, flake fragments and debris, made on flint pebbles $(70.2 \%$, tabl. 1$)$ or 
quartz pebbles (14\%). The retouched tools are almost equally divided between light duty tools (made on flint for $78.8 \%$ of them) and heavy duty tools (made on sandstone for $74.8 \%$ of them, fig. 11 and tabl. 1). Retouched flake tools are mostly denticulates (68.2\%), scrapers (19.7\%) and notches (12.1\%, Ravon et Monnier, 2013). Therefore, layer 4 appears to be the level with the highest number of scrapers within the site (Ravon, in progress). Heavy duty tools are mostly choppers and pebbles with single removals, which seems to result from their use as hammerstones. Two very distinct chaînes opératoires are already present since the beginning of the collection of the different raw materials within or in the environment of the site. Indeed, the cobble tools were made on sandstone, microgranite or quartzite cobbles, and the debitage products were made on flint, or quartz pebbles, these being naturally available in the fossil beaches in or surrounding the deposit.

The only raw material that does not come from a pebble is the glossy sandstone which comes from an outcrop situated ca. $20 \mathrm{~km}$ from the site. This raw material must have been knapped nearby the outcrop, or outside Menez-Dregan, for cores are totally absent in the lithic assemblage, only flakes, flake fragments and retouched light duty tools remain to show us the use of this raw material.

The main characteristics of the lithic industry of layer 4 are: large quantity of pebble tools (almost 6\%), great variety of shapes and supports for the retouched light duty tools, debitage products that tend to be shorter and thicker than in the previous layers.

As for the cores $(4,3 \%$ of the assemblage), they were made via alternate flaking mainly, from a striking platform obtained after the removal of at least one flake, or two or three unipolar and parallel flakes. Usually, only two core episodes are present, but it can vary with the size and shape of the raw material used. Most of the cores are made on flint, and the smallest pebbles used to obtain flakes are a result of bipolar flaking on an anvil. Two discoid cores are present in the assemblage, and were made on larger quartzite pebbles. These are the only discoid cores present on the site so far.

\section{Discussion}

We have presented briefly the lithic industry of layer 4, which simultaneously combines Lower Palaeolithic characteristics, such as large quantities of pebble tools (due to the environment of the site) and "opportunistic" knapping, and the emergence of characteristics that are common to the Middle Palaeolithic, such as standardisation of flake production, and knapping methods adapted to the dimensions of the raw materials (discoid knapping for quartzite, bipolar flaking on an anvil for small flint pebbles).

The standardisation of flake production leads us to foresee a change in the lithic industry of layer 4, and allows us to highlight a transitional period from the Lower Palaeolithic to the Middle Palaeolithic in the latest occupation of this deposit (Ravon and Monnier, 2013). The presence of cobble tools within the assemblage is a common characteristic shared by all the layers in Menez-Dregan I, but in different proportions. Layers 4 and 7 have the biggest quantity of cobble tools within the site $(6,7 \%$ for layer $4,6 \%$ for layer 7$)$. The ability to create desirable cobble tools is likely one of the primary reasons early Palaeolithic people came to settle in Menez-Dregan I cave. Indeed, the presence of the various raised beaches in the area proved to be a reserve of raw materials of a great variety, and furthermore available in large quantities. The large amount of cobble tools in layer 4 seems to be an unchanged component in the lithic industry of the site, due to environmental constraints. 
Highlighting this transitional period is rather complex in the south of Brittany, for Middle Palaeolithic sites are absent in the immediate neighbouring area around Menez-Dregan I. The nearest Early Middle Palaeolithic site present in the region is the site of Piégu, at Pléneuf-Val-André, on the northern coast of Brittany (fig. 12). This open air site dating from the end of OIS 7 has been excavated at the end of the 80's, and is composed of two main levels of human occupation, at the bottom of a cliff, next to a river (Monnier, 1985). Two different but broadly contemporaneous specialized areas coexist on the site: an activity of butchery on top of the cliff (level G), and a knapping floor at the bottom of it (level F). ESR/Useries dating for level $G$ on faunal remains gave an age of $200 \pm 16$ ky on teeth and $197 \pm 12$ ky on bones (Bahain et al., 2012; Laforge, 2012). The lithic industry at Piégu is made on flint, from a Levallois debitage (24\%) which led to the production of numerous unretouched points and flakes. The retouched light duty tools mainly compose of elaborated scrapers (ca. $50 \%$ ) of various types (Monnier, 1980). This lithic industry has been attributed to a Mousterian of Levallois facies, and can be linked to the Early Middle Paleolithic (Monnier et al., 2011).

Although the Levallois method is lacking at the site of Menez-Dregan I, some common characteristics exist in both assemblages, such as the production and use of unretouched flakes, and the presence of "Mousterian" scrapers of various types and shapes, but always rather elaborated. Furthermore, the Levallois method is also absent on the more recent Middle Palaeolithic site of Les Vallées in Pléneuf-Val-André (fig. 12; Huet, 2010). Therefore, the presence or absence of the Levallois method cannot allow us to attribute a site to the Middle Paleolithic in the Brittany region.

More generally, the period of transition between Lower and Middle Palaeolithic seems complicated to highlight (Monnier, 2006). The Middle Palaeolithic appears rather early in the region, such as in the North of France, where the complexity of the nature of this transition has been demonstrated (Tuffreau et al., 2008). Objective criterias of attribution to the Middle Paleolithic seem impossible to define, only the systematisation of flake production, or the adaptation of knapping methods to the available raw materials seem to help us to foresee this transition (Colonge et al., 2010). A systematical production of flakes and tools on flake supports, typologically sophisticated and clearly differentiated can also be a good indication (Tuffreau, 1979).

\section{Conclusion}

This study is a contribution to document the variability of the Lower Palaeolithic assemblages, and the variability in the indications of the transition between Lower and Middle Palaeolithic. In layer 4, although we have the presence of what we could call opportunistic knapping, in the sense that the cores are usually not well reduced, and we also have the presence of a large amount of cobble tools, we can see a change in the composition of the lithic industry. In this layer, the ratio of scrapers is more important than in the older layers of the site, although there is still a large amount of denticulate tools. The production of flakes seems to be more standardised too, and one of the aims of the knappers in this layer appears to be attempting to obtain short and thick products that resemble Mousterian tools for some of them. They also adapted their knapping methods to the dimensions of the raw materials, like discoid knapping for big quartzite pebbles, or bipolar flaking on anvil for some small flint pebbles. But even if we can see the beginning of this transition here, the unchanged component in the lithic industry of Menez-Dregan I, the thing that is most characteristic of this site, is the production of cobble tools, due to the availability 
of the raw materials around the site. The presence of these large pebbles on or around the site has determined this technical behaviour in the Brittany region during the Lower and Middle Palaeolithic.

It seems likely that one of the main reasons Palaeolithic populations settled on this site is due to the presence of fossil beaches in the area. We think this resource of raw material determined the choices they made for their lithic industry. In regards to the geology, there are absolutely no naturally occurring outcrops of flint in Brittany. The only accessible sources of flint are small marine flint pebbles, naturally found within the local fossil beaches, eroded from a submerged outcrop of cretaceous flint situated $40 \mathrm{~km}$ from the site (fig. 13; Lefort et al., 2007). Their dimensions (max. $10 \mathrm{~cm}$ ) would not have allowed the Palaeolithic occupants of the site to make cobble tools. Instead, they chose to use sandstone, microgranite and quartzite to create their heavy duty tools. Furthermore, the natural shape of these elongated and rather flat cobbles would have assisted in determining the function of the tool created, and it seems likely that cobbles were selected for these properties. This behaviour persisted from layer 9 to layer 4, during probably $200 \mathrm{ky}$.

\section{Acknowledgments}

The authors would like to thank Josephine Mills and Tabitha Paterson for their proofreadings of the manuscript, and Pierre Stéphan (LETG-Géomer, Brest) for his DTM of the $-60 \mathrm{~m}$ sea level. We also thank Rebecca Scott and Marta Arzarello for their reviews and helpful comments on this document.

\section{References}

Bahain, J.-J., Falguères, C., Laurent, M., Shao, Q., Dolo, J.-M., Garcia, T., Douville, E., Franck, N., Monnier, J.-L., Hallegouët, B., Laforge, M., Huet, B., Auguste, P., Liouville, M., Serre, F., Gagnepain, J., 2012. ESR and ESR/U-series dating study of the Middle Palaeolithic site of Piégu (Brittany, France). A multi-material approach. In: 13th International Conference on Luminescence and Electron Spin Resonance Dating, Torun, Poland, 10-14th july 2011, Quaternary Geochronology, LED2011 Special Issue, 10, 424-429.

Colonge, D., Jarry, M., Delfour, G., Fondeville, C., avec la collaboration de Arnoux, T. et Berthet, A.-L., 2010. De la transition Paléolithique inférieur-moyen dans la vallée de la Garonne : l'Acheuléen supérieur de Raspide 2 (Blagnac, Haute-Garonne), Bulletin de la Société préhistorique française, 107, 2, 205-225.

Forestier, H., 1993. Le Clactonien : Mise en application d'une nouvelle méthode de débitage s'inscrivant dans la variabilité des systèmes de production lithique du Paléolithique ancien. Paléo, 5, 53-82.

Huet, B. (dir.), 2010. Le site Paléolithique moyen des Vallées (Pléneuf-Val-André, Côtesd'Armor). Rapport final d'opération programmée.UMR $6566 \mathrm{CReAAH}$, Ministère de la Culture et de la Communication, DRASSM, SRA Bretagne, Rennes, $62 \mathrm{p}$.

Laforge, M., 2012. Le cadre chronostratigraphique des peuplements pléistocènes de l'Ouest de la France. Eustatisme, changements climatiques et occupations humaines. Thèse de doctorat de I'Université Rennes 1, France, 266 p. 
Laforge, M., Huet, B., 2013. Variations eustatiques pléistcènes sur la côte de Penthièvre (Côtes-d'Armor, France) au cours des trois derniers cycles interglaciaire/glaciaire et occupations paléolithiques associées. In : Daire, M.-Y., Dupont, C., Baudry, A., Billard, C., Large, J.-M., Lespez, L., Normand, E. Scarre, C. (dir.), 2013. Ancient Maritime Communities and the Relationship between People and Environment along the European Atlantic Coasts / Anciens peuplements littoraux et relations Homme/Milieu sur les côtes de l'Europe atlantique. Proceedings of the HOMER 2011 Conference, Vannes (France), 28 sept - 1 oct 2011. British Archaeological Reports, International Series 2570, Oxford : Archeaopress, 615-623.

Laforge, M., Monnier, J.-L., 2011. Contribution à la chronostratigraphie du gisement Paléolithique inférieur de Menez-Dregan 1 (Plouhinec, Finistère, France). Corrélations avec les dépôts de la falaise de Gwendrez. Quaternaire, 22, (2), 91-104.

Lefort, J.-P., Monnier, J.-L., Marcoux, N., 2007. Apport de la géologie marine à la détermination des sources de matières premières au Paléolithique dans le Massif armoricain : Origine possible du silex utilisé sur les stations paléolithique inférieur de MenezDregan (Plouhinec, Finistère, France). Implications paléoclimatiques et paléoenvironnementales. Quaternaire , 18, (3), 233-241.

Lisiecki, L. E., Raymo, M. E., 2005. A Pliocene-Pleistocene stack of 57 globally distributed benthic D180 records. Paleoceanography, vol. 20, PA1003, doi:10.1029/2004PA001071.

Marcoux, N., Aoustin, D., Monnier, J.-L., Hallegouët, B., Hinguant, S., in preparation. Séquence archéobotanique du OIS 9 de la côte Est atlantique. La couche 5 de Menez Dregan I (Bretagne, France).

Mercier, N., Froget, L., Miallier, D., Pilleyre, T., Sanzelle, S., Tribolo, C., 2004. Nouvelles données chronologiques pour le site de Menez-Dregan 1 (Bretagne) : l'apport de la thermoluminescence. Quaternaire, 15, (3), 253-261.

Molines, N., 1999. Les industries à galets aménagés du littoral sud-armoricain (France) au Paléolithique inférieur. Thèse de l'Université Rennes 1. BAR International Series 795, 275 p.

Molines, N., Monnier, J.-L., Hinguant, S., Hallegouët, B., 2005. L'Acheuléen de l'Ouest de la France : apports du site de Menez-Dregan 1 (Plouhinec, Finistère, France). In : Molines, N., Moncel, M.-H., Monnier, J.-L. (Eds), Les premiers peuplements en Europe. Colloque international de Rennes, sept . 2003, BAR International Series 1364, 533-544.

Monnier, G., 2006. The Lower/Middle Paleolithic Periodization in Western Europe, Current Anthropology, 47, 709-744.

Monnier, J.-L., 1980. Le Paléolithique de la Bretagne dans son cadre géologique. Thèse de Doctorat d'État, Travaux du Laboratoire d'Anthropologie, Rennes, 607 p.

Monnier, J.-L., 1985. Données nouvelles sur le gisement paléolithique moyen de Piégu (Pléneuf-Val-André, Côtes-du-Nord). Revue archéologique de l'Ouest, 2, 7-21. 
Monnier, J.-L., 1996. Acheuléen et industries archaïques dans le Nord-Ouest de la France. In: Tuffreau, A. (Ed.), L'Acheuléen dans l'Ouest de l'Europe. Actes du colloque de SaintRiquier, 6-10 juin 1989. Publications du CERP, Lille, $n^{\circ} 4,145-154$.

Monnier, J.-L., Le Cloirec, R., 1985. Le gisement paléolithique inférieur de la Pointe de SaintColomban, Carnac, Morbihan. Gallia Préhistoire, 28, 6-36.

Monnier, J.-L., Molines, N., 1993. Le Colombanien: un faciès régional du Paléolithique inférieur sur le littoral armoricano-atlantique. Bulletin de la Société préhistorique française, 90, 283-294.

Monnier, J.-L., Hallegouët, B., Hinguant, S., 1996. Rapport de fin d'opération pluri-annuelle sur la fouille du gisement paléolithique inférieur de Menez-Dregan I à Plouhinec, Finistère. Rennes, $321 \mathrm{p}$.

Monnier, J.-L., Huet, B., Laforge, M., 2011. Application of sedimentological analysis to the correlation of eroded layers under beaches with local and regional Pleistocene stratigraphy. A contribution to geological dating of Palaeolithic sites on Northern coast of Brittany (France). Quaternary International, 232, 78-94.

Monnier, J.-L., Hinguant, S., Molines, N., Hallegouët, B., 2000. Rapport intermédiaire sur la fouille du gisement paléolithique inférieur de Menez-Dregan I, campagne 2000, Rennes, $40 \mathrm{p}$.

Monnier, J.-L., Hallegouët, B., Hinguant, S., Molines, N., 2001. La datation de l'habitat Paléolithique inférieur de Menez-Dregan 1 (Plouhinec, Finistère, France). Argumentation géologique et archéologique. Actes des XXle Rencontres Internationales d'Archéologie et d'Histoire d'Antibes : Datation (19-21 octobre 2001), 261-277.

Monnier, J.-L., Hallegouët, B., Hinguant, S., Falguères, C., Laurent, M., Yokoyama, Y., Auguste, P., Bahain, J.-J., Marguerie, D., Molines, N., Morzadec, H., 1994. A new regional group of the Lower Palaeolithic in Brittany (France) recently dated by Electron Spin Resonance. Comptes Rendus de l'Académie des Sciences, Paris, 319, II, 155-160.

Ravon, A.-L., in progress. Originalité et développement du Paléolithique inférieur à l'extrémité occidentale de l'Eurasie : le «Colombanien » de Menez Dregan I (Plouhinec, Finistère). Thèse de doctorat de l'Université Rennes 1, France.

Ravon, A.-L., Monnier, J.-L., 2013. La transition Paléolithique inférieur-moyen dans l'Ouest armoricain : l'exemple de la couche 4 du site de Menez-Dregan1 (Plouhinec, Finistère). Bulletin de la Société préhistorique française, 110, 1, 7-23.

Shackelton, N., 1987. Oxygen isotopes, ice volume and sea level. Quaternary Science Reviews, vol. 6, n³-4, 183-190.

Tuffreau, A., 1979. Les débuts du Paléolithique moyen dans la France septentrionale. Bulletin de la Société préhistorique française, 76, 5, 140-142.

Tuffreau, A., Lamotte, A., Goval, E., 2008. Les industries acheuléennes de la France septentrionale. The Acheulean industries of Northern France. L'anthropologie, 112, 104-139. 
Waelbroeck, C., Labeyrie, L., Michel, E., Duplessy, J. C., McManus, J. F., Lambeck, K., Balbon, E., Labracherie, M., 2002. Sea-level and deep water teperature changes derived from benthic foraminifera isotopic records. Quaternary Science Reviews, 21, 295-305. 


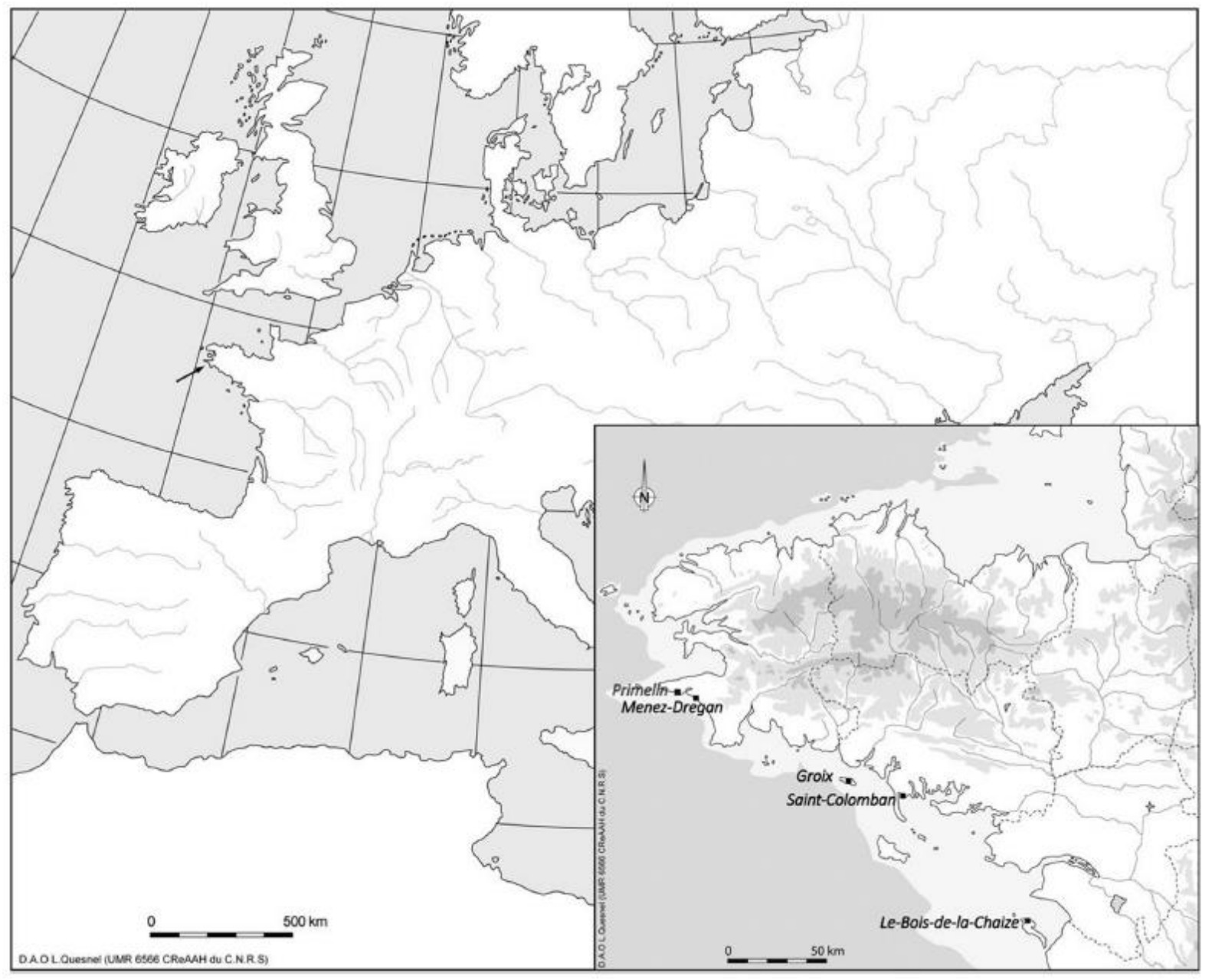

Fig. 1: Geographic location of the Lower Palaeolithic site of Menez Dregan I (CAD: L. Quesnel). 


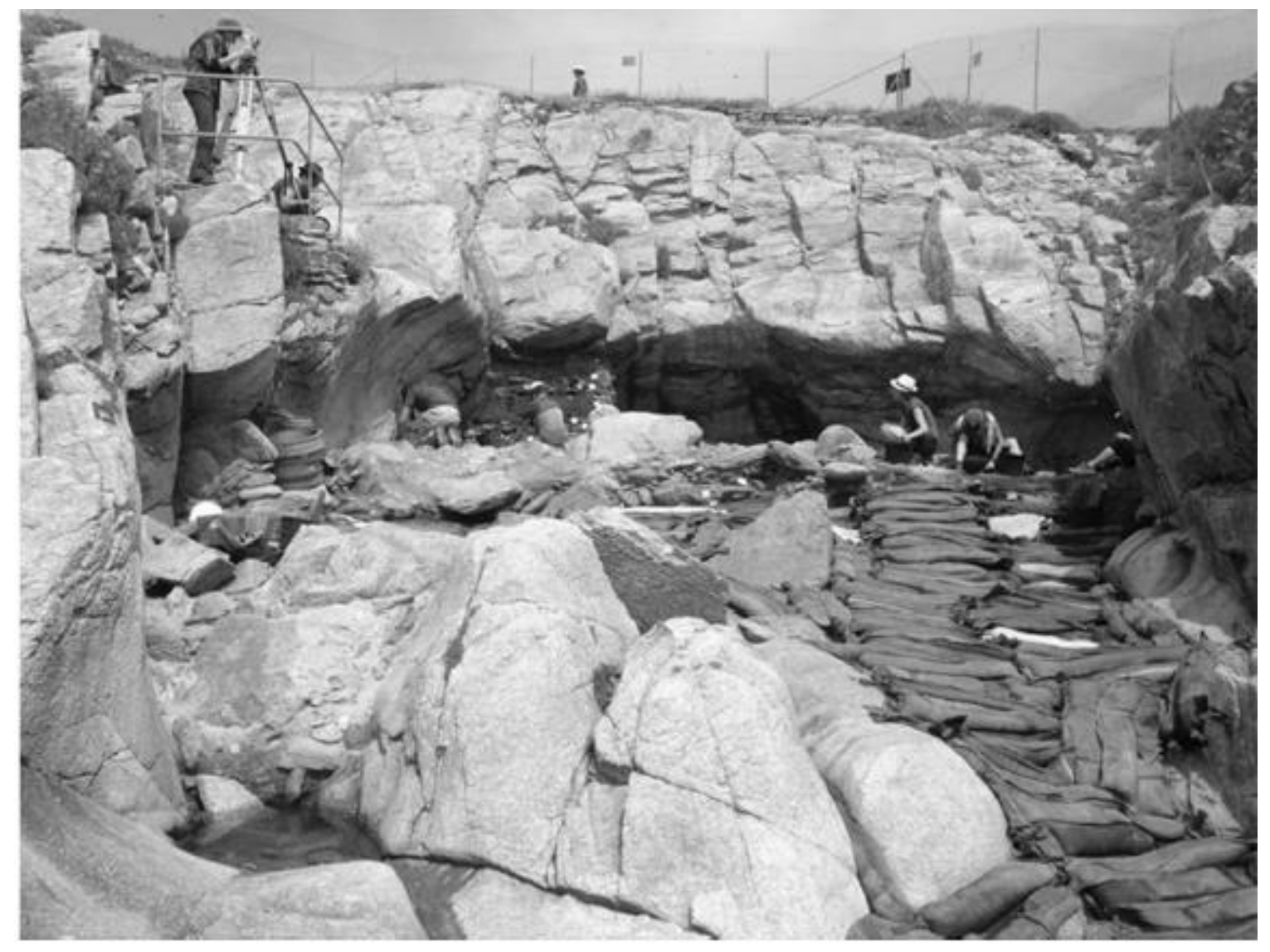

Fig. 2: The site of Menez-Dregan I, view from the south (Photo J.-L. Monnier). 


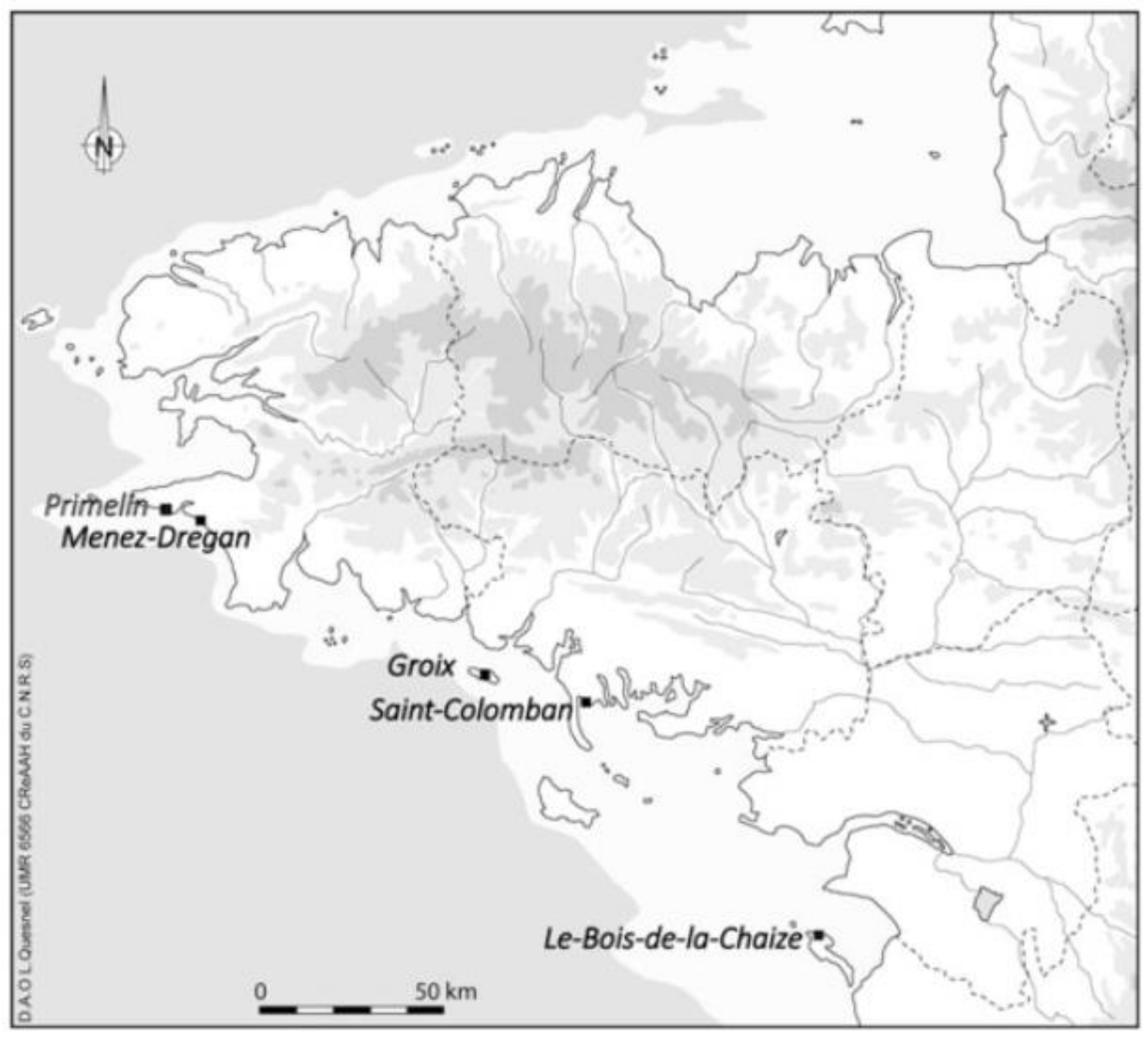

Fig. 3: Map showing the distribution of the Colombanian sites (CAD: L. Quesnel \& A.-L. Ravon). 


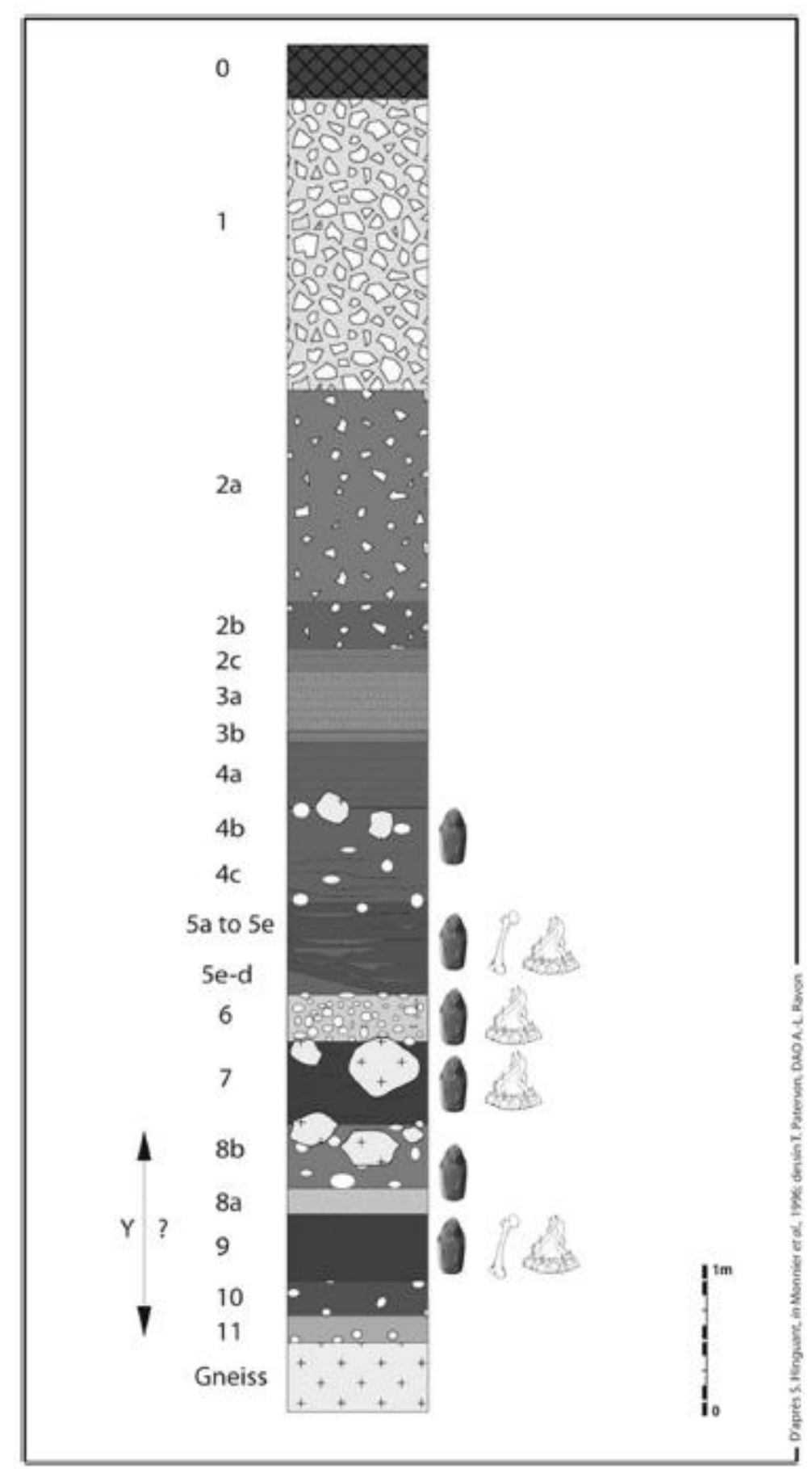

Fig. 4: Stratigraphy of the Lower Palaeolithic site of Menez-Dregan I. Drawings: T. Paterson, CAD: A.-L. Ravon. (After S. Hinguant, in Monnier et al., 1996, modified). 0: present-day soil; 1: coarse head which filled up the deep (this is the last cold period recorded at the site); $2 \mathrm{a}$ : large blocks and flagstones, from the final collapse of the marine cave; 2b: arenaceous head; 3a: flaky and argillaceous sand (littoral dune); 3b: Set sandy crust; 4a to 4c: flaky head mixing marine sand and pebbles, with palaeolithic tools (mainly $4 \mathrm{~b}$ ) and strained black layers at its base (4c); 5 a to $5 \mathrm{e}$ : anthropic soils alternating black (presence of charcoals) and brown layers, very rich with lithic industry, with the presence, at the top of $5 \mathrm{c}$, of a structure of combustion; $5 \mathrm{e}-\mathrm{d}$ : disturbed ash-bearing layer with structure of combustion arranged at the top of the underlying pebble beach; 6: pebble beach; 7: alternation of Paleolithic layers and dark organic layers, with rounded and smoothed blocks from the collapsed cave, and presence of pebbles at its basis; $8 \mathrm{~b}$ : raised beach with rocks from the collapsed roof; 8a: sandy layer from the raised beach (8b); 9: sandy-loamy layer, with lithic tools, bones and charcoals, presence of a structure of combustion in a pit; 10: raised beach; 11: raised beach; gneiss: bedrock. 


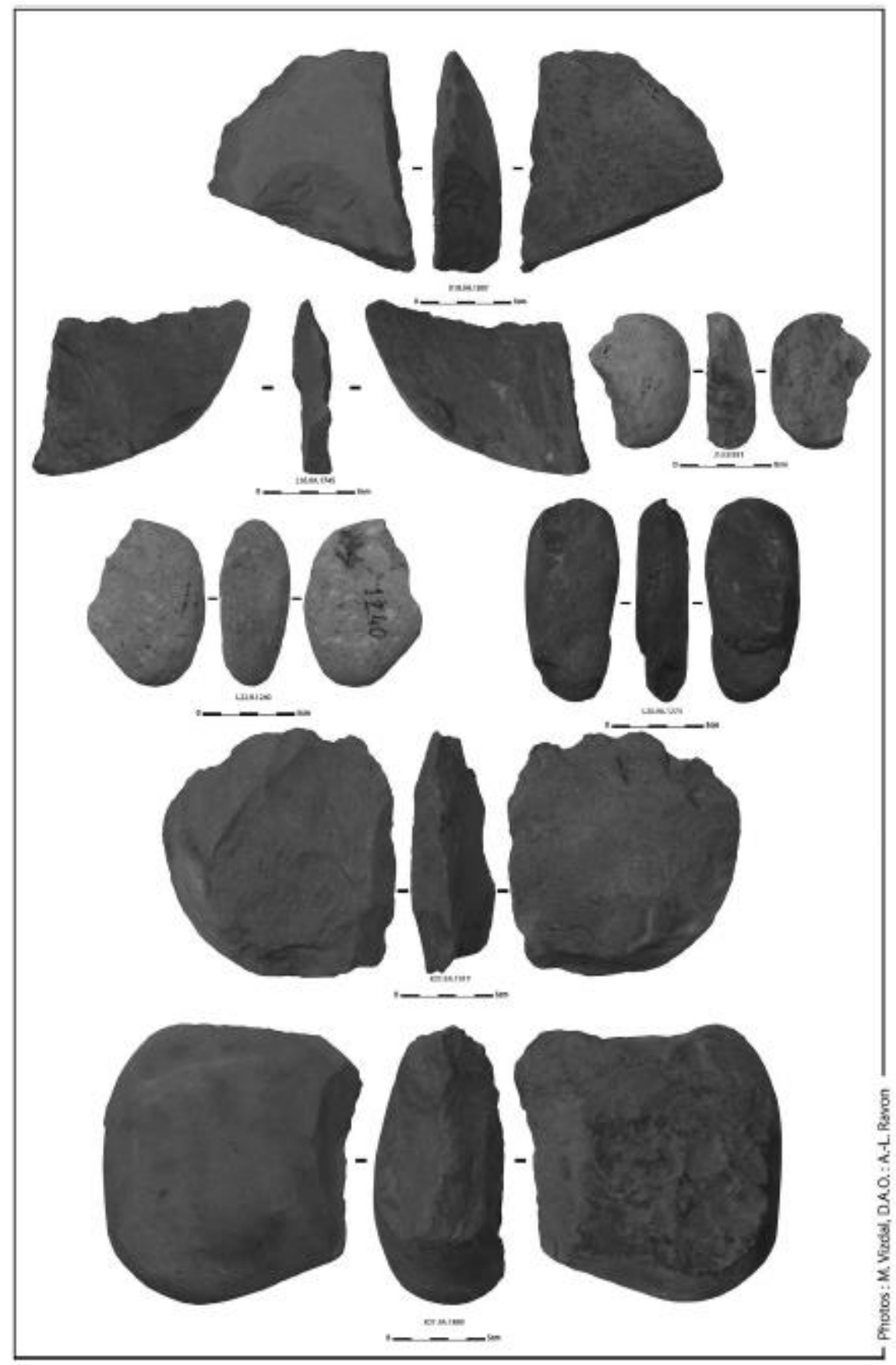

Fig. 5: Lithic industry from Menez-Dregan I, layer 9 (Photos: M. Vizdal, CAD A.-L. Ravon). 

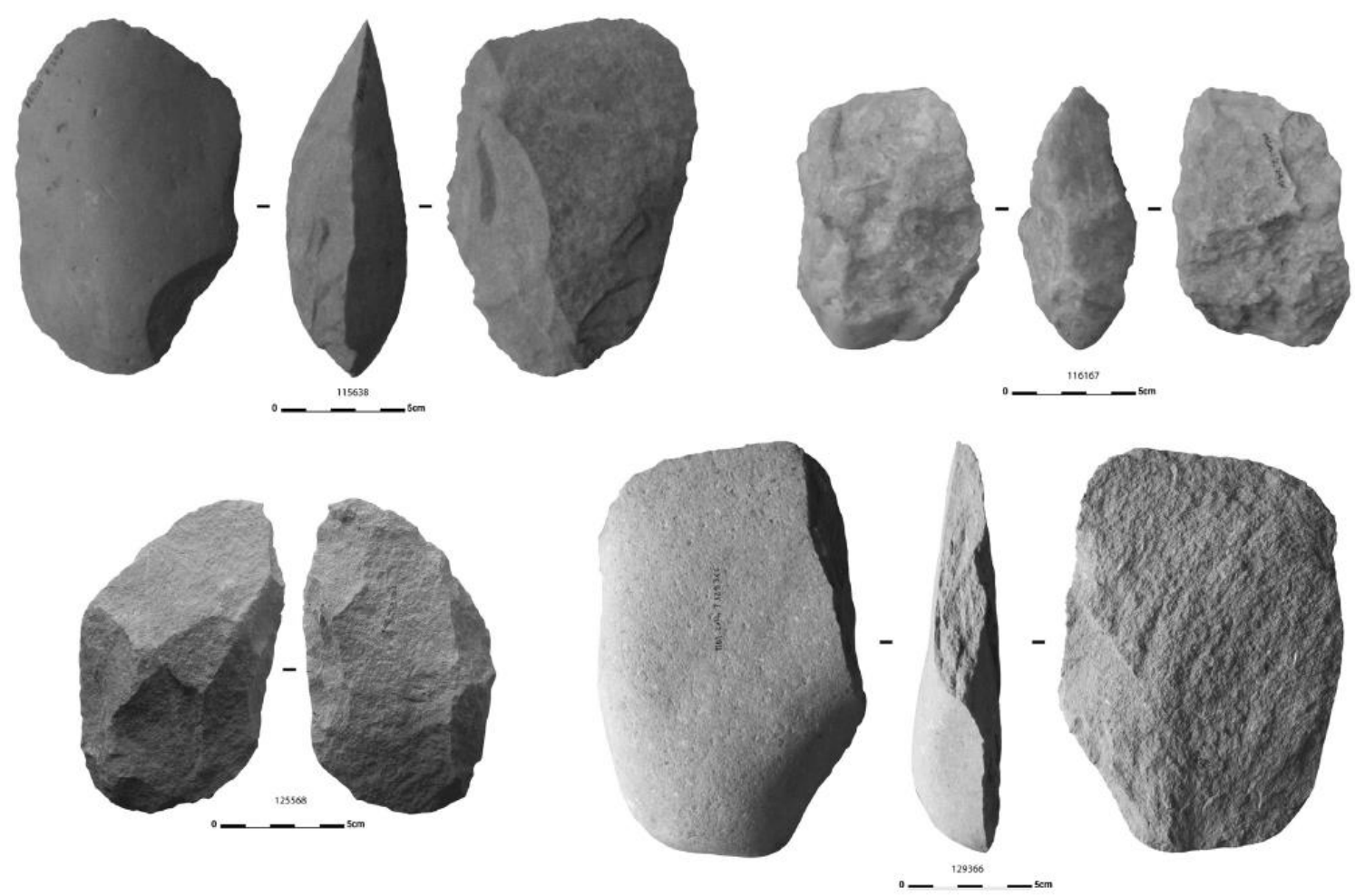

Fig. 6: Lithic industry from Menez-Dregan I, cleavers in layer 7 (Photos: R. Cheruel, C. Gaillard \& A.-L. Ravon, CAD: A.-L. Ravon). 


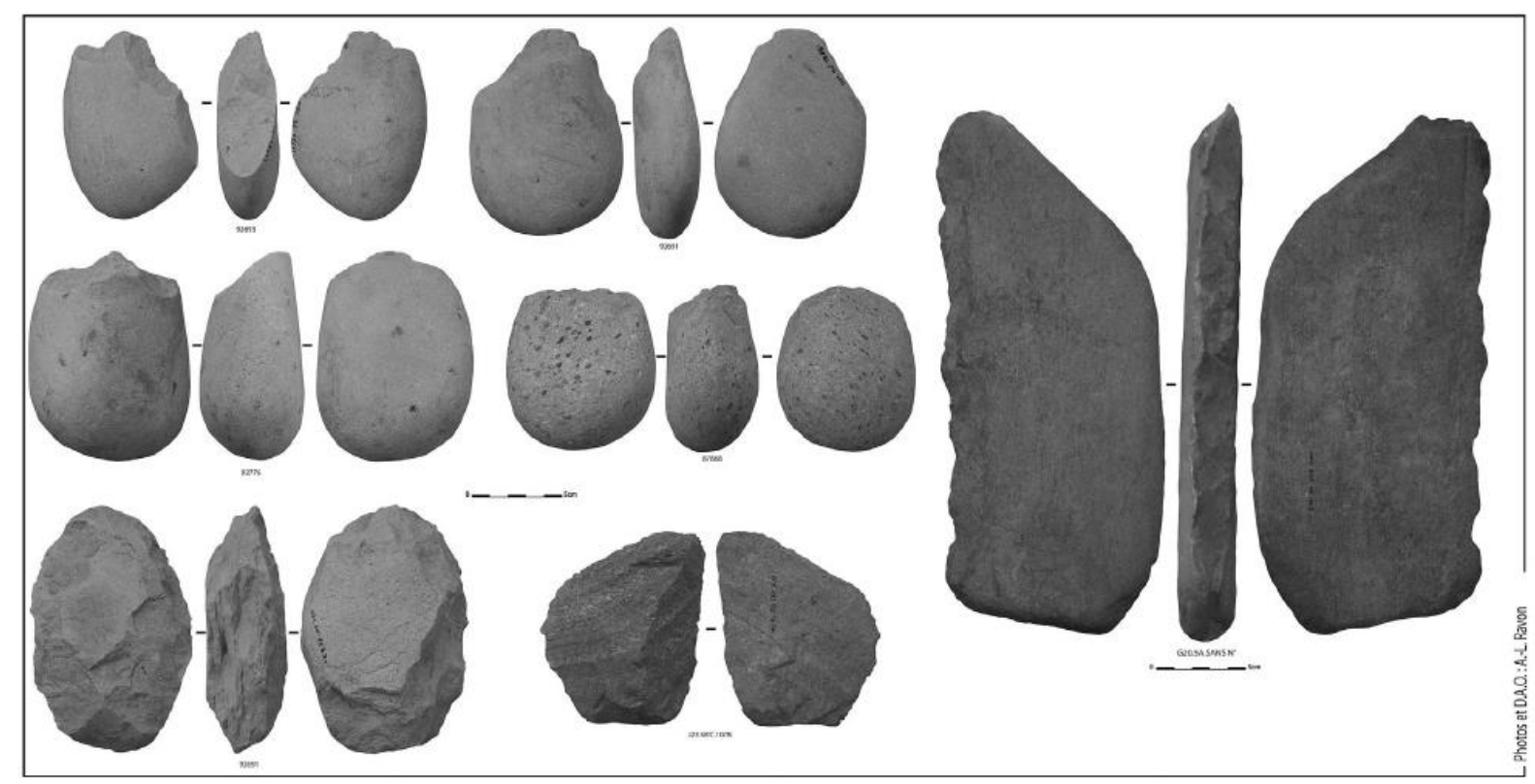

Fig. 7: Lithic industry from Menez-Dregan I, layer 5 (Photos \& CAD: A.-L. Ravon).

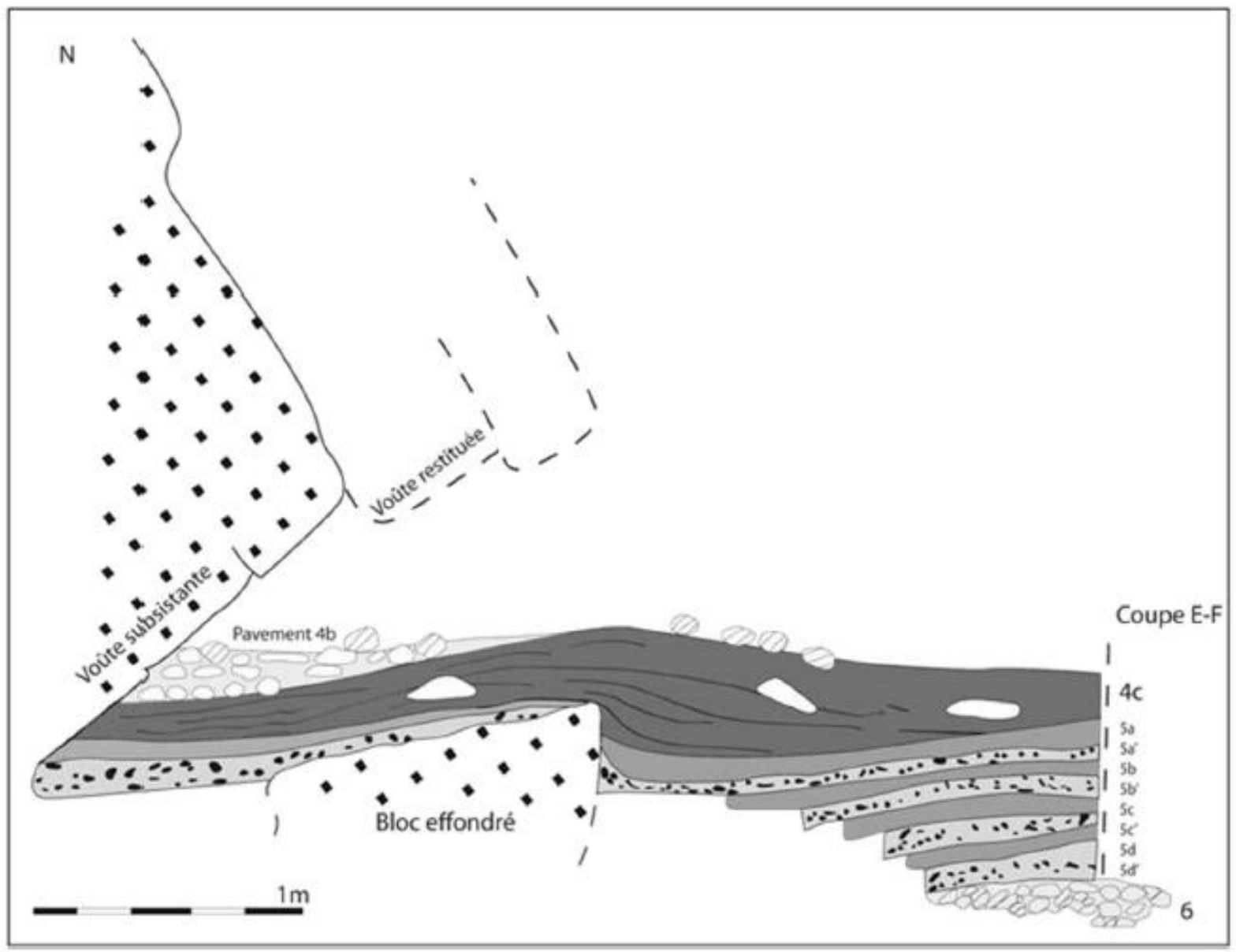

Fig. 8: Paving structure in layer 4b (after S. Hinguant in Monnier et al., 2000; CAD: F. Sotin). 


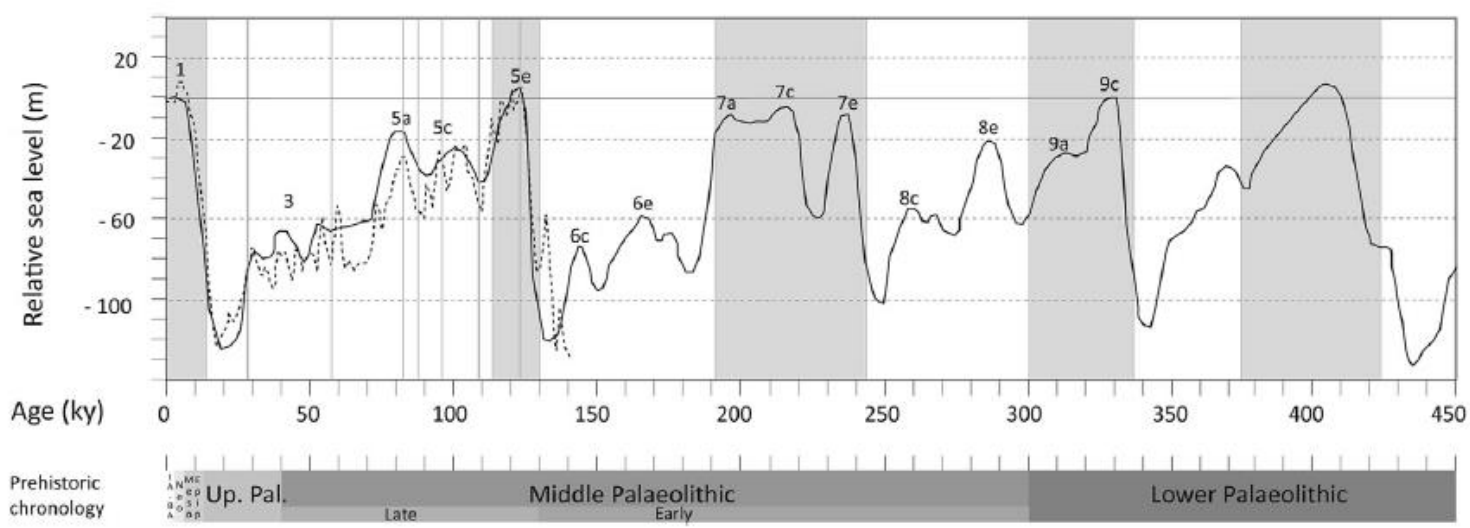

Fig. 9: Relative sea levels and chronological distribution of the isotopic stages for the last 450 ky, after the work of Waelbroeck et al., 2012; Shackelton, 1987; Lisiecki and Raymo, 2005. (In Laforge, 2012, p. 94, modified).

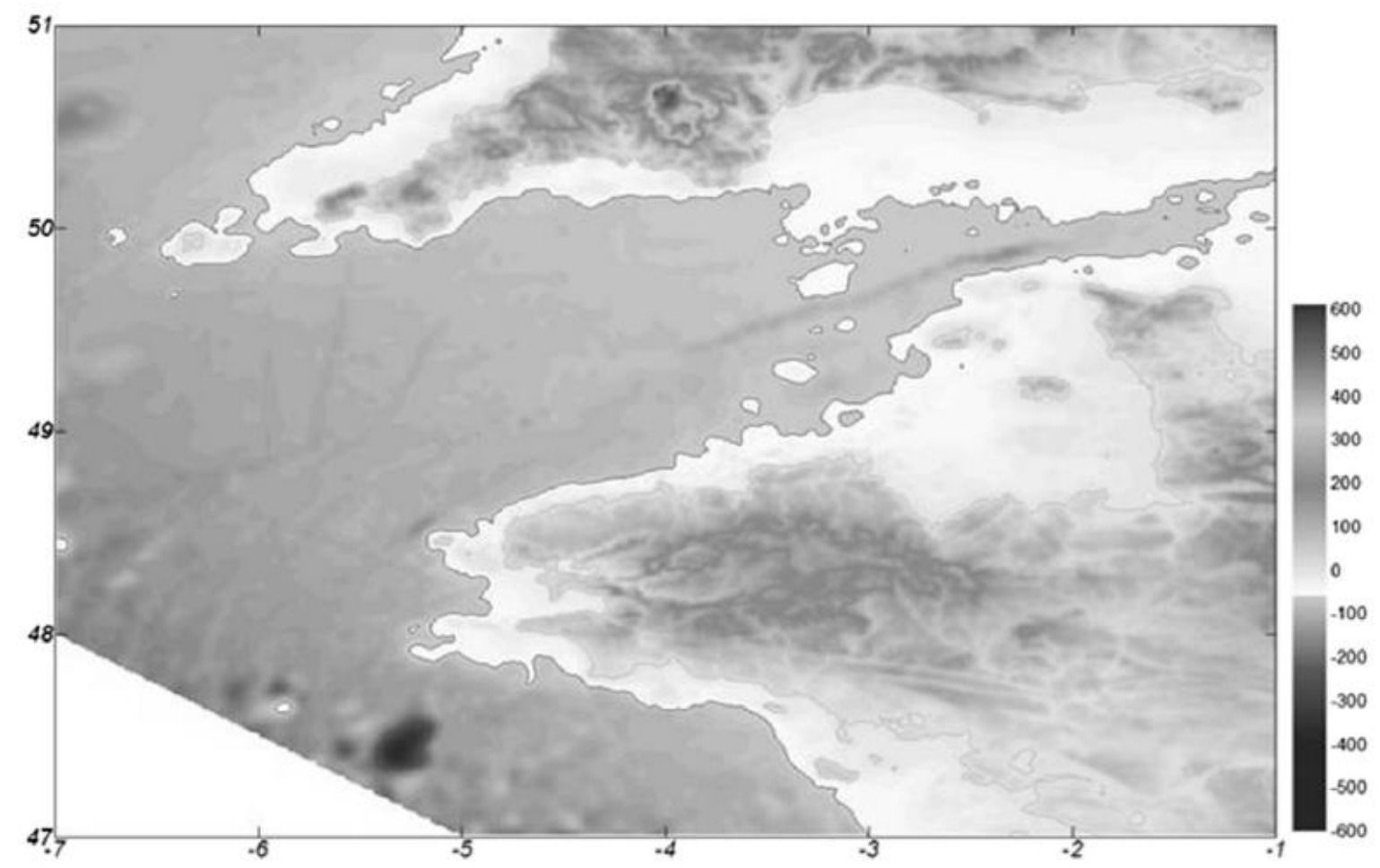

Fig. 10: Digital Terrain Model for a sea level of - 60 m (DTM P. Stéphan, LETG-Géomer, Brest; in Laforge, 2012, p. 147). 
Table 1

Composition of the lithic assemblage in layer 4 .

\begin{tabular}{|c|c|c|c|c|c|c|c|c|}
\hline Nature & Flint & Quartz & Sandstone & Quartzite & Microgranite & Glossy sandstone & Total & $\%$ \\
\hline Flakes (incl. Broken) & 6800 & 1056 & 762 & 59 & 344 & 44 & 9065 & $60.8 \%$ \\
\hline Debris & 1518 & 607 & 435 & 29 & 178 & 11 & 2778 & $18.6 \%$ \\
\hline Retouched light duty tools & 849 & 66 & 81 & 14 & 51 & 17 & 1078 & $7.2 \%$ \\
\hline Pebble tools & - & 27 & 631 & 3 & 183 & - & 844 & $5.8 \%$ \\
\hline Cores & 541 & 71 & 4 & 14 & 12 & - & 640 & $4.3 \%$ \\
\hline Pebble fragments & 6 & 34 & 121 & 3 & 70 & - & 234 & $1.6 \%$ \\
\hline Miscellaneous & 60 & 39 & 26 & 2 & 17 & - & 144 & $0.9 \%$ \\
\hline Hammerstones & - & 11 & 82 & - & 33 & - & 126 & $0.8 \%$ \\
\hline Total & 9774 & 1911 & 2142 & 122 & 888 & 72 & 14,909 & $100 \%$ \\
\hline$\%$ & $65.6 \%$ & $12.8 \%$ & $14.4 \%$ & $0.8 \%$ & $5.9 \%$ & $0.5 \%$ & $100 \%$ & \\
\hline
\end{tabular}

Tabl. 1: Composition of the lithic assemblage in layer 4.

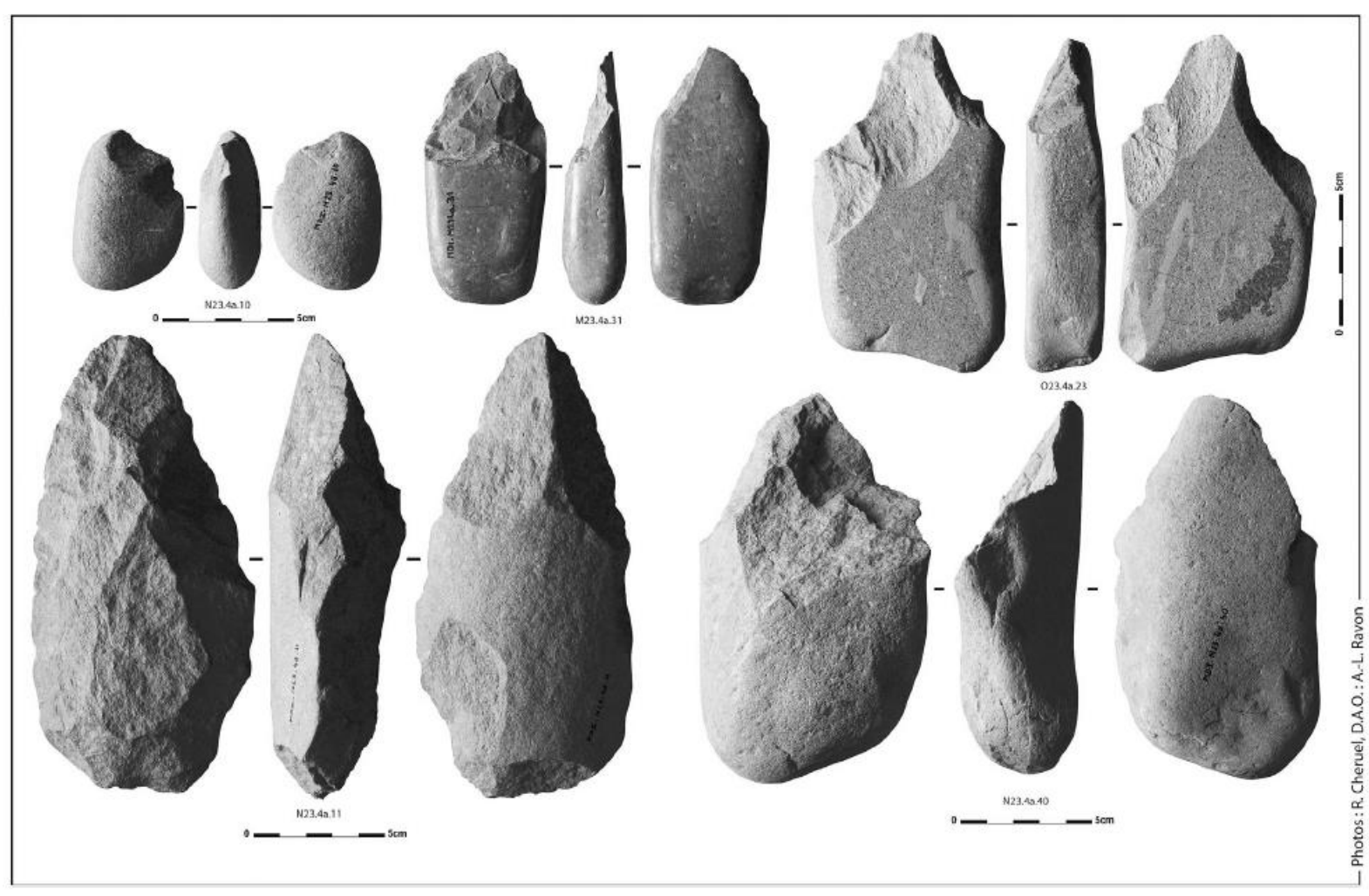

Fig. 11: Layer 4, cobble tools (Photos: R. Cheruel, CAD: A. L. Ravon). 


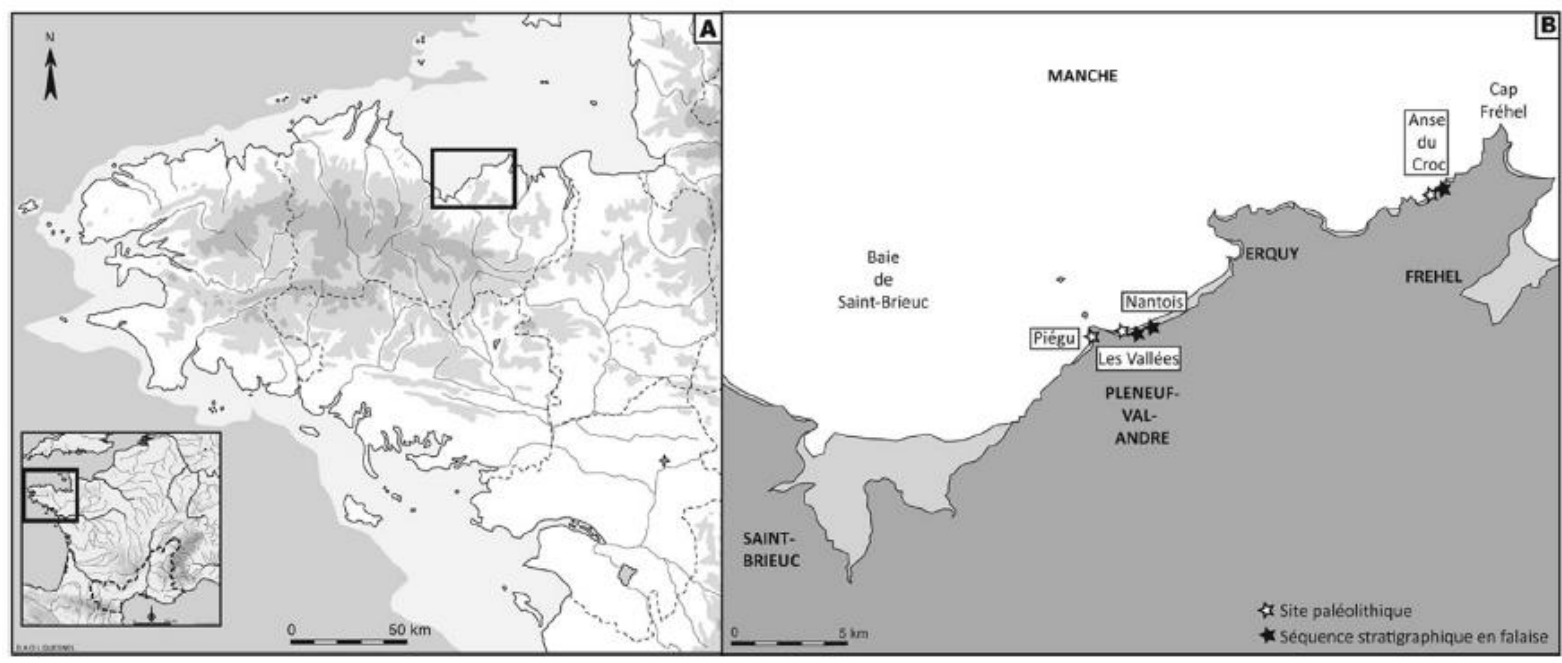

Fig. 12: Location of the site of Piégu in A - Brittany and B - the East of the bay of SaintBrieuc (in Laforge and Huet, 2013, p. 615). 


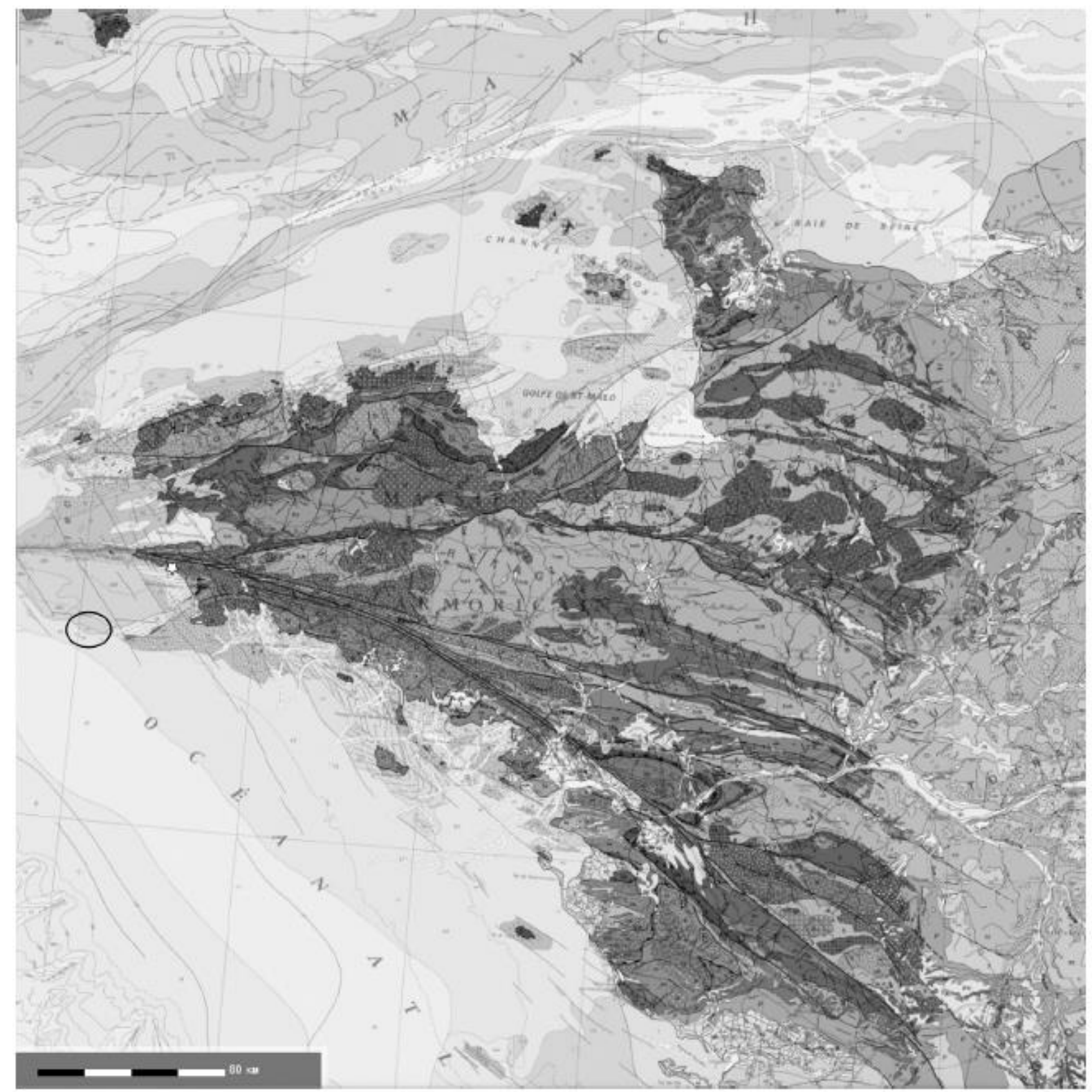

Fig. 13: Geological map of North Western France, showing the location of the site of MenezDregan I (white star) and the location of the nearest cretaceous flint outcrop (in black circle). Extrait de la carte géologique de France au 1/1 000 000ème, éd. B.R.G.M., Orléans. CAD: A. L. Ravon. 